Jurnal Ilmu Olahraga Volume I Nomor 1 Oktober 2018

Antonius S, Belka Farlin, M.Suprayogi, Thoribius R, Nopensah, Reza \& Bardiono

Tersedia di: http://jurnal.untan.ac.id/index.php/jilo

\title{
DESKRIPSI KEMAMPUAN GERAK DASAR (MELEMPAR, MELOMPAT DAN MENENDANG) SISWA KELAS SATU (1) SEKOLAH DASAR.
}

Antonius S, Belka Farlin, M.Suprayogi, Thoribius R, Nopensah, Reza \& Bardiono

\begin{abstract}
Abstrak
Latar belakang penelitian untuk mengevaluasi kualitas gerak anak usia 5 sampai 7 tahun. Tujuan penelitian kami untuk mengetahui tingkat kualitas gerak anak dalam tiga aspek yaitu melelmpar, melompat dan menendang. Metode penelitian menggunakan penelitian survai dengan tes dan pengukuran.. Sampel 21 anak kelas 1 SD, yang terdiri dari 11 putra dan 10 putri. Data pendukung dilakukan rekaman video. Hasil penelitian menunjukan kualitas gerak tertinggi pada melompat dengan nilai $66 \%$, sementara kualitas menendang dan melempar masing-masing 62\%. Kesimpulan bahwa kualitas gerak yang terdiri dari tiga item gerak dasar siswa sekolah dasar, ternyata tingkat penguasaan gerak dasar siswa sekolah dasar tingkat penguasaan gerak lebih dari 50\% sudah berkemampuan tinggi. Dengan kata lain kemampuan gerak dasar siswa sekolah dasar masih 50:50.
\end{abstract}

Kata kunci : keterampilan gerak dasar, melompat, melempar, menendang,

Abstract

\section{DESCRIPTION STUDENT'S FUNDAMENTAL MOVEMENT SKILLS (THROW, JUMP, AND KICK) FIRST GRADES ELEMENTARY SCHOOL}

Antonius S, Belka Farlin, M.Suprayogi, Thoribius R, Nopensah, Reza \& Bardiono

\begin{abstract}
Abtract
Back ground of this research for evaluated quality of movement child 5-7 years old. The aaim this study to descript the three aspect about throw, jump and kick. Survey method used in this research with test and mearement. Sampels are 21 student first grade elementary school, 11 boys and 10 girls. Video is used for documentary. Research shown the quality of jump about $66 \%$, cicking and throwing about $62 \%$ each. Based on the reseact founded, student quality of movement in first grades elementary school about $50 \%$ have hight level, the other side $50 \%$ are still basic.
\end{abstract}

Key words: fundamental movement skill 


\section{A. PENDAHULUAN}

Penilaian keterampilan gerak adalah komponen penting dari berbagai disiplin ilmu dan profesi pendidikan jasmani. Secara khusus, efektivitas program peningkatan kualitas gerak bergantung pada informasi yang akurat tentang tingkat keterampilan siswa. Informasi ini harus berdasarkan penilaian yang valid, komprehensif, edukatif, adil dan eksplisit. Sebagai contoh, (EDWA, 2001) tes skrining terhadap empat item, pada langkah awal pembelajaran yang dilakukan guru yang telah dilakukan dapat untuk mengidentifikasi tingkat keterampilan koordinasi anak-anak (Larkin \& Revie, 1994).

Penilaian yang dilakukan selain dengan tes dilihat dan diukur dengan menggunakan lembar observasi dengan analisis berdasarkan tes kualitatif. Knudson dan Morrison (1997, p.4) mendefinisikan penilaian kualitatif sebagai "pengamatan sistematis dan penentuan kualitas gerakan manusia untuk tujuan masukan yang paling tepat intervensi untuk meningkatkan kinerja ".

$$
\text { Tahapan dan tingkatan }
$$

perkembangan gerak bersifat umum baik itu lengan, tungkai ataupun togok, kesemuanya memiliki tahapan-tahapan yang harus dilalui. Semua bagian anggota tubuh akan mengalami kemajuan secara bersamaan sampai pada tingkat efisien. Untuk melihat ini dapat dilihat berdasarkan pada pengamatan, dimana pengamatan ini berdasarkan pada indikator diskripsi secara per bagian dari setiap angota bagian tubuh yang telah disusun dan didefinisikan dalam tahapan belajar (Seefeldt \& Haubenstricker, 1982).

Pengembangan keterampilan gerak dasar pada anak dapat diukur dengan cara uji atau test seperti yang di lakukan oleh Walkley (1993) menggunakan data kualitatif dan hasil evaluasi tingkat keterampilan gerak dasar mengunakan sampel sebanyak 1182 anak di sekolahsekolah di Victoria pada anak usia 2, 4, 6, dan 8 tahun dengan menggunakan komponen keterampilan gerak, kemudian dikembangkan secara khusus untuk penelitian tersebut. Dari hasil laporan tersebut ditemukan rendahnya tingkat kemampuan untuk semua keterampilan yang didasarkan pada penguasaan kriteria keterampilan gerak yang di tes. Kemudian Departemen Pendidikan bersama-sama Universitas Tasmania menggunakan Uji keterampilan gerak kasar (Ulrich, 1985) yang akan difungsikan untuk mengukur keterampilan gerak kasar pada tingkatan keterampilan gerak dengan menggunakan sampel sebanyak 574 anak-anak berusia 710 tahun (Cooley, Oakman, McNaughton, \& Ryska, 1997). Tes ini memberikan hasil dari data kualitatif untuk menilai 12 kriteria keterampilan gerak, dengan penilaian poin di persentil kesetiap kriteria tersebut. Alat penilaian keterampilan motoric kasar melibatkan catatan pengamatan yang bervariasi disesuaikan dengan kriteria nomor keterampilan gerak untuk setiap satu keterampilan. McIntyre (2000) menganalisis rekaman video anak-anak yang melakukan gerakan melempar menggunakan 3 alat penilaian yang berbeda. Tes ini menggunakan uji keterampilan gerak kasar (Ulrich, 1985) dengan membandingankan data keterampilan gerak dari (Departeman pendidikan Victoria, 1996) dengan data keterampilan gerak (Departemen Pendidikan Australia Barat, 1997).

Penguasaan keterampilan gerak dasar pada akhirnya bermanfaat untuk memberikan modal rasa percaya diri anak, ketika anak menguasai keterampilan gerak dasar melempar dengan baik maka pada tahap belajar selanjutnya akan lebih mudah dalam mempelajari keterampilan teknik melempar dalam kasti, basket ataupun voli. Hal ini mengindikasikan bahwa penguasaan gerak dasar sangat penting. 
Anak akan mengalami kemudahan dalam belajar ketika memiliki modal yang cukup. Ketika belajar mudah dan anak mengalami sukses dalam belajar akan semakin memperbesar kemungkinan untuk anak berpartisipasi dalam aktivitas jasmani. Dengan partisipasi dalam aktivitas jasmani maka anak akan selalu bergerak, dengan bergerak akan mendapatkan keuntungan yang besar dalam peningkatan kulitas gerak anak tersebut.

Berdasarkan pada paparan terdahulu maka peneliti akan melakukan studi kecil tentang studi kasus keterampilan gerak dasar siswa dan siswi SD kelas satu. Data dari penelitian ini

Diharapkan dapat menjadi gambaran kecil tingkat penguasaan gerak dasar siswa sekolah dasar.

Berdasarkan latar belakang permasalahan di atas, Sebagai sebuah bukti empiris penguasaan keterampilan gerak dasar, masalah permasalahan yang akan diungkap adalah bagaimana kemampan gerak dasar siswa SD kelas satu (1)?

\section{B. METODE PENELITIAN}

Penelitian ini merupakan penelitian deskriptif. Dalam melakukan penelitian melibatkan sebanyak 21 anak kelas 1 SD N 2 Desa Kapur Kab. Kubu Raya, yang terdiri dari 11 putra dan 10 putri. Dalam memudahkan analisis data, mengunakan nomor dada secara acak kepada 21 anak tersebut. Alat penunjang yang digunakan dalam penelitian bola kasti dan papan sasasaran (digunakan sebagai penunjang dalam analisis gerak melempar). Kun dan hand ball ( digunakan dalam penunjang gerak menendang) dan kartu game sebagai media pelengkap dalam gerak melompat.

Masing-masing anak melakukan gerakan melompat sebanyak tiga kali pengulangan, gerakan melempar dua kali dan gerak menendang sebanyak dua kali pengulangan secara berurutan. Selama melakukan gerak melempar, menedang dan melompat kami menggunakan video rekaman untuk mempermudah dalam menganalisis data.

Sebelum melakukan gerak disampaikan instrumen gerak kepada seluruh anak, selain disampaiakan dengan ilustrasi dan penjelasan, contoh gerak diberikan agar lebih mudah memahami. Instrumen dalam masing-masing gerakan beragam, pada gerak melompat sub nilai maksimal adalah 11, yang terdiri dari awalan (3 gerakan), melayang (4 gerakan) dan mendarat (4 gerakan). Pada gerak menendang sub nilai makasimal adalah 12 , yang terdiri dari awalan (4 gerakan), saat menendang (5 gerakan) dan akhiran (3 gerakan). Pada gerak melempar sub maksimal dalam instrumen adalah 7 , yang terdiri dari awalan (4 gerakan), dan saat lemparan (3 gerakan).

Metode Dalam Perhitungan hasil tes

Penskoran Hasil Tes

Pada instrumen melempar

Nilai yang diperoleh $\div$ sub maksimal instrumen

Contoh (n1) percobaan pertama :

Sub maksimal instrumen $\quad=7$

Nilai yang diperoleh $\quad=4$

Maka :

Nilai yang diperoleh $\div$ sub maksimal instrumen $=4 \div 7$

$=0,56$, karena kualitas satuanya menjadi $\%$, maka di kali $100=0,57 \times 100=\mathbf{5 7} \%$

Metode ini juga berlaku pada perhitungan gerak Melompat dan Menendang

\section{HASIL PENELITIAN DAN PEMBAHASAN}

1. Hasil Penelitian

Data dianalisis dengan menggunakan statistik deskriptif sederhana yaitu persentase.

Hasil penelitan dikelompokkan atas 3 bagian; pertama berdasarkan jenis kelamin putra, kedua putri dan yang ketiga secara keseluruhan. Hal ini dilakukan agar 
memudahkan memahami data. Adapun

hasil akhir analisis sebagai berikut:

Tabel 1. Hasil putra dan putri

\begin{tabular}{|l|c|c|c|c|c|c|c|}
\hline \multicolumn{5}{|c|}{ Putra } & & \multicolumn{3}{c|}{ Putri } \\
\hline Rentang & lempar & nendang & lompat & Nilai & lempar & nendang & lompat \\
\hline $80-100$ & 3 & 4 & 4 & A & 1 & - & 4 \\
\hline $70-80$ & 5 & 3 & 3 & B & 4 & 1 & 2 \\
\hline $60-70$ & 2 & 1 & 1 & C & - & - & - \\
\hline $50-60$ & - & 2 & 1 & D & - & 3 & 2 \\
\hline$<50$ & 2 & 1 & 2 & E & 4 & 6 & 2 \\
\hline Jumlah & 12 & 12 & 11 & & 21 & 21 & 21 \\
\hline
\end{tabular}

$\mathrm{L}=11$

Tabel 2. Hasil keseluruhan

\begin{tabular}{|c|c|c|c|c|}
\hline Rentang & $\begin{array}{l}\text { melem } \\
\text { par }\end{array}$ & Menendang & Melompat & $\begin{array}{l}\text { jumlah keseluruhan anak yang melakukan } \\
\text { gilaik menendang dikalikan } 100 \% \text {. }\end{array}$ \\
\hline $80-100$ & 4 & 4 & 8 & $\overline{\mathrm{A}}$ rata - rata $=100 \%\left(\frac{11}{21}\right)$ \\
\hline $70-80$ & 9 & 4 & 5 & $\begin{array}{l}\quad \mathbf{= 5 2}, \mathbf{3 8} \% \\
\text { Hasil kualitas menendang rata-rata }\end{array}$ \\
\hline $60-70$ & 2 & 1 & 1 & $\begin{array}{l}\text { putri } 47,61 \% \text { hasil ini didapatkan dari } \\
\text { jumlah siswa yang melakukan gerak }\end{array}$ \\
\hline $50-60$ & - & 5 & 3 & $\begin{array}{l}\text { menendang pada penilaian putri sebanyak } \\
10 \text { orang dengan nilai }(\mathrm{A})=0 \text {, nilai }(\mathrm{B})=1\end{array}$ \\
\hline$<50$ & 6 & 7 & 4 & $\begin{array}{l}\text { orang, nilai }(C)=0 \text {, nilai }(D)=3 \text { orang, dan } \\
\text { nilai }(E)=6 \text { orang, dilakukan perhitungan }\end{array}$ \\
\hline Jumlah & 21 & 21 & 21 & $\begin{array}{l}\text { dengan cara : } \\
\text { Jumlah sample penelitian }(n)=21 \text { orang }\end{array}$ \\
\hline $\begin{array}{l}\text { Hasi } \\
\text { menendang } \\
\text { hasil ini did } \\
\text { melakukan } \\
\text { penilaian } 1 \\
\text { dengan nila } \\
\text { orang, nilai } \\
\text { orang, dan } \\
\text { perhitungan } \\
\mathrm{n}=21\end{array}$ & $\begin{array}{l}\text { penel } \\
\text { utra rat: } \\
\text { atkan da } \\
\text { gerak } \\
\text { i-laki } \\
\text { (A) }=4 \\
\text { C) }=1 \\
\text { lai (E) } \\
\text { ilakukan }\end{array}$ & $\begin{array}{l}\text { ian ketera } \\
\text { rata adalah } 5 \\
\text { i: jumlah sisw } \\
\text { menendang } \\
\text { ebanyak } 11 \\
\text { orang, nilai ( } \\
\text { rang, nilai (I } \\
1 \text { orang, ker } \\
\text { dengan cara : }\end{array}$ & $\begin{array}{r}\text { npilan } \\
2,38 \% \\
\text { a yang } \\
\text { pada } \\
\text { orang } \\
=3 \\
=2 \\
\text { ludian }\end{array}$ & 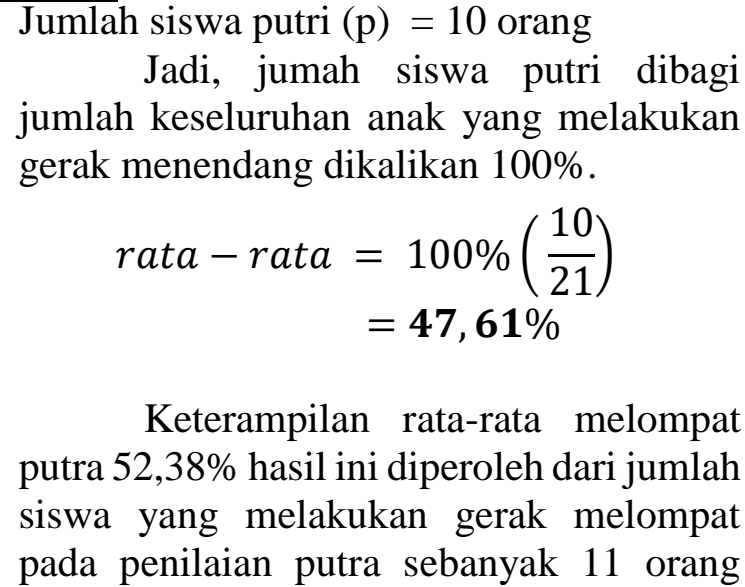 \\
\hline
\end{tabular}


dengan nilai $(A)=4$ orang, nilai $(B)=3$ orang, niai $(\mathrm{C})=1$ orang, nilai $(\mathrm{D})=1$ orang, dan nilai $(\mathrm{E})=2$ orang dilakukan perhitungan dengan cara :

Jumlah sample penelitian (n) $=21$ orang Jumlah siswa putra $(\mathrm{L})=11$ orang Jadi, jumah siswa putri dibagi jumlah keseluruhan anak yang melakukan gerak melompat dikalikan $100 \%$.

$$
\begin{aligned}
\text { rata }- \text { rata } & =100 \%\left(\frac{11}{21}\right) \\
& =\mathbf{5 2}, \mathbf{3 8} \%
\end{aligned}
$$

Hasil kualitas melompat rata-rata putri 47,61 \% hasil ini didapatkan dari jumlah siswa yang melakukan gerak melompat pada penilaian putri sebanyak 10 orang dengan nilai $(A)=4$ orang, nilai $(B)$ $=2$ orang, nilai $(C)=0$, nilai $(D)=2$ orang, dan nilai $(E)=2$ orang, dilakukan perhitungan dengan cara :

Jumlah sample penelitian (n) $=21$ orang

Jumlah siswa putri $(\mathrm{p})=10$ orang

Jadi, jumah siswa putri dibagi jumlah keseluruhan anak yang melakukan gerak melompat dikalikan $100 \%$.

$$
\begin{aligned}
\text { rata }- \text { rata } & =100 \%\left(\frac{10}{21}\right) \\
& =\mathbf{4 7}, \mathbf{6 1} \%
\end{aligned}
$$

Keterampilan melempar putra ratarata kemampuanya adalah $57,14 \%$ hasil ini didapatkan dari jumlah siswa yang melakukan gerak melompat pada penilaian putri sebanyak 12 orang dengan nilai $(\mathrm{A})=$ 3 orang, nilai $(B)=5$ orang, nilai $(C)=2$ orang, nilai $(D)=0$, dan nilai $(E)=2$ orang, dilakukan perhitungan dengan cara :

Jumlah sample penelitian (n) $=21$ orang Jumlah siswa putri $(\mathrm{p})=12$ orang

Jadi, jumah siswa putri dibagi jumlah keseluruhan anak yang melakukan gerak melempar dikalikan $100 \%$.

$$
\begin{aligned}
\text { rata }- \text { rata } & =100 \%\left(\frac{10}{21}\right) \\
& =\mathbf{5 7}, \mathbf{1 4} \%
\end{aligned}
$$

Keterampilan melempar putri ratarata adalah 42,85 \% hasil ini didapatkan dari jumlah siswa yang melakukan gerak melompat pada penilaian putri sebanyak 9 orang dengan nilai $(A)=1$ orang, nilai $(B)$ $=4$ orang, nilai $(C)=0$, nilai $(\mathrm{D})=0$, dan nilai $(E)=4$ orang, dilakukan perhitungan dengan cara :

Jumlah sample penelitian (n) $=21$ orang Jumlah siswa putri $(\mathrm{p})=9$ orang

Jadi, jumah siswa putri dibagi jumlah keseluruhan anak yang melakukan gerak melempar dikalikan $100 \%$.

$$
\begin{aligned}
& \text { rata }- \text { rata }=100 \%\left(\frac{9}{21}\right) \\
& =\mathbf{4 2 , 8 5} \% \\
& \text { Jadi, secara } \quad \text { keseluruhan } \\
& \text { keterampilan melempar rata-rata } \\
& \text { kemampuanya adalah } 61,5 \% \text {, kemampuan } \\
& \text { menendang } 61,76 \% \text {, dan } \\
& \text { melompat } 66,33 \% \text { Kemampuan }
\end{aligned}
$$

\section{Pembahasan}

Berdasarkan hasil tabulasi dan analisis data dapat dilihat bahwa siswa dengan keterampilan melempar putra ratarata memiliki kemampuan yang kurang baik, berdasarkan penilaian gerak yang telah dilakukan, begitu juga pada siswi putri pada test melempar yang dilakukan, diperoleh hasil yang masih kurang memuaskan. Kerena setiap keterampilan motorik agak berbeda antar satu dengan yang lainnya, maka setiap jenis kegitan atau aktivitas gerak seharusnya di pelajari satupersatu (Bil Keane, 1975). Kemudian untuk memperoleh keterampilan gerak halus (Fine motor skill) yang baik memerlukan kemampuan untuk mengontrol otot halus atau kecil untuk mencapai pelaksanaan keterampilan gerak yang sukses. Menurut Magill (1985), keterampilan ini melibatkan koordinasi neuro muscular yang memerlukan ketepatan derajat tinggi untuk berhasilnya keterampilan gerak yang memerlukan koordinasi mata-tangan 
(Hand-Eye Coordination). Hasil penelitian yang telah dilakukan ini, pada keterampilan menendang putra rata-rata adalah $52,38 \%$ berkemampuan baik dan keterampilan menendang putri rata-rata $47,61 \%$. Keterampilan rata-rata melompat putra 52,38\% dan putri 47,61 \%. Keterampilan melempar putra rata-rata kemampuannya adalah $57,14 \%$ dan keterampilan melempar putri rata-rata adalah $42,85 \%$. secara keseluruhan keterampilan melempar rata-rata kemampuanya adalah $61,5 \%$, kemampuan menendang $61,76 \%$, dan Kemampuan melompat $66,33 \%$.

Hasil penelitian ini memberikan bukti empiris bahwa keterampilan gerak dasar siswa SD kelas 1 baik putra dan putri berbeda, hal ini sesuai dengan teori yang dinyatakan oleh (Jones, 1965) Temuantemuan atas anak-anak perempuan yang lebih cepat matang pun serupa tetapi tidak sekuat pada anak laki-laki, teori ini di perkuat oleh Schmidt yang menilai kualitas gerak itu sendiri di tentukan dengan kualitas gerakan itu sendiri. Artinya kematangan dalam menentukan keterampilan gerak pada anak laki-laki lebih baik dari pada anak perempuan. Yang menyatakan bahwa keterampilan gerak kasar ketika anak putra menggerakan kakikaki dengan lebih percaya diri dan membawa diri pada tujuan yang lebih khusus, proses bergerak ke sekitar di dalam lingkunganya menjadi lebih otomatis (Poes $\&$ Others, 1990). Sehingga dengan aktifnya anak putra dalam aktivitas jasmani dan kebiasaan mencoba berulang-ulang menunjukan pada kualitas gerak anak putra yang lebih baik dari anak perempuan secara umum. Pada usia 3 tahun, anak-anak masih suka akan gerakan sederhana, seperti berjingkat-jingkat, melompat dan berlari kesana kemari. anak sampai usia 5 tahun akan lebih berani mengambil resiko, bukan sesuatu yang luar biasa bagi anak anak untuk melakukan ketangkasan yang mengerikan seperti memanjat dan sebagainya.

Berdasarkan sudut pandang perkembangan motorik anak usia sekolah dasar memperoleh kendali lebih besar atas tubuh mereka. Tindakan fisik penting bagi siswa, hal ini untuk memperhalus keterampilan gerak mereka yang sedang berkembang, seperti memukul bola, melompat tali, atau melakukan gerak keseimbangan di atas balok. Oleh karena itu, pada prinsinya anak sekolah dasar harus terlibat secara aktif dari pada pasif di dalam kegiata-kegiatan (Katz \& Chard, 1989). Anak-anak pada usia enam tahun akan dapat melakukan gerak seperti memukul bola, mengikat sepatu, meninju dan mengancing baju. Pada usia tujuh tahun menjadi lebih kuat, anak anak lebih menyukai pensil dari pada krayon untuk melukis, dan tulisan pun menjadi lebih kecil. Pada usia delapan sampai sepuluh tahun koordinasi motorik harus berkembang, siswa mampu menulis huruf lebih kecil dan rata. Anak-anak usia sepuluh sampai dua belas tahun sebelum memasuki usia puber dinyatakan menurut (Brooks-Gunn,1988,1992; Hood 1991; Paikoff, Buchanan, \& Brooks-Gunn, 1991) memiliki tingkat keterampilan yang sama, sehingga dalam aplikasi bermain dan aktivitas jasmani dapat disamakan, menurut Schmidt (1991) keterampilan gerak, penentu utama dari gerak itu sendiri tanpa memperhatikan persepsi serta pengambilan keputusan yang berkaitan dengan kerampilan yang dipilih.

Berdasarkan teori belajar gerak dapat dipahami bahwa orang akan belajar melaui 3 tahapan; pertama kognisi, asosiasi, dan otomatisasi. Pada umur anak usia 6-7 tahun yang merupakan kelas 1 SD merupakan masa anak pada fundamental movement phase yaitu gerak dasar dimana secara perkembangan gerak tersebut pada tahap mature stage atau kematangan gerak, 
anak telah memiliki gerak dasar dengan baik.

\section{KESIMPULAN}

Disimpulkan bahwa kualitas gerak akan sangat dipengaruhi oleh kematangan otot dan syaraf anak itu sendiri. Kematangan otot seperti kemampuan otot tangan, yaitu pundak, lengan dan jari, sedangkan otot bawah seperti kemampuan otot kaki secara keseluruhan. Sementara kemampuan syaraf sangat dipengaruhi dari usia anak itu sendiri, dalam mengimplementasikan instrument yang disampaikan. Hasil penelitian yang telah dilakukan, pada keterampilan menendang putra rata-rata adalah $52,38 \%$ dan keterampilan menendang putri rata-rata $47,61 \%$. Keterampilan rata-rata melompat putra 52,38\% dan putri 47,61 \%. Keterampilan melempar putra rata-rata kemampuanya adalah $57,14 \%$ dan keterampilan melempar putri rata-rata adalah 42,85 \%. secara keseluruhan keterampilan melempar rata-rata kemampuanya adalah $61,5 \%$, kemampuan menendang $61,76 \%$, dan Kemampuan melompat $66,33 \%$.

Hasil penelitian ini memberikan bukti empiris bahwa keterampilan gerak dasar siswa SD kelas 1 baik putra dan putri berbeda, hal ini sesuai dengan teori yang dinyatakan oleh (Jones, 1965) Temuantemuan atas anak-anak perempuan yang lebih cepat matang pun serupa tetapi tidak sekuat pada anak laki-laki, teori ini di perkuat oleh Schmidt yang menilai kualitas gerak itu sendiri di tentukan dengan kualitas gerakan itu sendiri. Artinya kematangan dalam menentukan keterampilan gerak pada anak laki-laki lebih baik dari pada anak perempuan. Yang menyatakan bahwa keterampilan gerak kasar ketika anak laki-laki mengerakan kaki-kaki mereka dengan lebih percaya diri dan membawa diri mereka ke tujuan yang lebih khusus, proses bergerak ke sekitar di dalam lingkunganya menjadi lebih otomatis (Poes \& Others, 1990). Sehingga dengan aktifnya anak laki-laki dalam aktivitas jasmani dan kebiasan mencoba berulangulang menunjukan pada kuliatas gerak mereka yang lebih baik dari anak perempuan secara umum.

Menurut PASI (1993), "gerak-gerak dasar pada anak usia 2-7 tahun adalah lari, lompat, melempar, menangkap dan menendang". Pada umur anak usia 6-7 tahun yang merupakan kelas 1 SD merupakan masa anak pada fundamental movement phase yaitu gerak dasar dimana secara perkembangan gerak tersebut pada tahap mature stage atau kematangan gerak, anak telah memiliki gerak dasar dengan baik. Secara garis besar siswa kelas satu (1) yang menjadi sampel penelitian baru $50 \%$ menguasai gerak dasar.

Ucapan terimakasih

Artikel ini adalah kerja kelompok kecil dalam latihan penelitian, pertama diucapkan terimakasih kepada team yang telah bekerjassma dalam menyelesaikan peneliitan sampai artikel. Kedua kepada kepala sekolah, guru kelas dan guru pendidikan jasmani SD N 2 Desa Kapur Kabupaten Kubu Raya yang dengan senang hati dan keramahan penuh keakraban meluangkan waktu dalam penelitian ini memberikan fasilitas dan izin. siswa siswa SD N 2 Desa Kapur yang telah bersedia menjadi sampel penelitian. Tidak lupa kepada Y. Touvan Juni Samodra selaku pembimbing.

\section{Daftar Pustaka}

Larkin, D. \& Hoare, D (1991).Out of Step: Coordinating kids' movement. Nedlands, WA: Active Life Foundation. 
Antonius S, Belka Farlin, M.Suprayogi, Thoribius R, Nopensah, Reza \& Bardiono Tersedia di: http://jurnal.untan.ac.id/index.php/jilo

Larkin, D., \& Revie, G. (1994).Stay in Step: A gross motor screening test forchildren $K-2$.Perth, WA: Authors.

Knudson, D. V., \& Morrison, C. S. (1997).Qualitative Analysis of Human Movement. Champaign, IL: Human Kinetics.

Seefeldt, V., \& Haubenstricker, J. (1982). Patterns, phases or stages: An analytical model for

the study of developmental movement. In J. A. S. Kelso \& J. E. Clark (Eds.), The development of of movement control and co-ordination (pp. 309-318). Chichester, England: Wiley.

Walkley, J., Holland, B., Treloar, R., \& Probyn-Smith, H. (1993). Fundamental motor skill proficiency of children. Australian Council for Health PhysicalEducation and Recreation, 40(3), 11-14.

Ulrich, D. A. (1985).Test of Gross Motor Development. Austin, TX: Pro-ED.

Cooley, D., Oakman, R., McNaughton, L., \& Ryska, T. (1997). Fundamental movement patterns in Tasmanian primary school children. Perceptual andMotor Skills, 84, 307-316.

McIntyre, F. (2000).Gender differences and developmental trends in the overarm throw:

Aqualitativ and quantitative analysis. Unpublished Honours, University of Western Australia, Perth.

Bil Keane. (1975). The Family Circus . Register and Tribune Syndicate.

Magill, Richard A. (1993). Motor Learning: Concept and Application (4th Ed).

WMC.Brown.Duboque. IA.

Schmidt, Richard A. (1991). Motor Learning and Performence: From principle into practice.Human kinetics. Champaign, IL.

Mahendra, A (2007:12). Teori belajar mengajar Motorik. Bandung.

Santrock, J.w. (2002). Perkembangan

Masas Hidup. Jakarta, Erlanga. 